\author{
КАТАРИНА МИТРИЋЕВИЋ-ШТЕПАНЕК* \\ Филолошки факултет Универзитета у Београду \\ Београд, Србија
}

\title{
ПРОУЧАВАњЕ ЧЕШКОГ ЈЕЗИКА НА КАТЕДРИ ЗА СЛАВИСТИКУ ФИЛОЛОШКОГ ФАКУЛТЕТА УНИВЕРЗИТЕТА У БЕОГРАДУ
}

\begin{abstract}
Рад је посвећен лингвистичким радовима наставника и сарадника Групе за чешки језик на Катедри за славистику Филолошког факултета у Београду. Даје преглед студија објављених у домаћим и страним часописима, као и монографија и докторских и магистарских теза које представљају допринос проучавању чешког језика у српској средини и пружају увид у развој научних интересовања у оквиру лингвистичке бохемистике.
\end{abstract}

Кључне речи: славистика, српска бохемистика, чешки језик, лингвистичка проучавања

О историјату настанка и развоја бохемистике на Катедри за славистику Филолошког факултета у Београду већ је доста писано. Подсетимо само да је настава чешког језика и књижевности почела да се одвија између два светска рата када на тадашњој Катедри за источне и западне словенске језике делује Отокар Колман, лектор за чешки језик, а прави оснивач катедре за бохемистику је Крешимир Георгијевић који после Другог светског рата ради на катедри као доцент чешке и словачке књижевности. ${ }^{1}$

Из прве генерације дипломираних бохемиста (1950) на катедри као предавачи остају Драгутин Мирковић и Стојанка Поповић. Лингвистичка интересовања Д. Мирковића крећу се од дијалектолошких, која обухватају проучавање чешких говора даруварског краја и чији је резултат обимна монографија Говори Чеха у Славонији (Дарувар и околина) (1968), ${ }^{2}$ настала на основу докторске дисертације, до транслатолошких, у оквиру којих објављује више радова о проблематици превођења, како

${ }^{*}$ kmitricevic@fil.bg.ac.rs

${ }^{1}$ О историјату бохемистике и научним интересовањима и радовима О. Колмана и К. Георгијевића писали су Д. Квапил, В. Копривица и А. Корда Петровић (2000).

2 Детаљни приказ ове монографије дали су Д. Квапил, В. Копривица и А. Корда Петровић (2000), те В. Копривица (2012), као и Павел Јанчак (Jančák 1970). 
о теорији, тако и пракси. У чланку „Семантичко-синтаксичке функције прозодијских елемената структуре стиха и њихова еквивалентност у уметничком преводу" (1974) осврће се на преводилачки поступак који је израстао у комплексну науку, наводећи притом бројне концепције и методе уз одговарајућу литературу и критички се осврћући на њих. Наводи такође да прозодијски елементи, као значајни фактор уметничкоестетског ефекта књижевног дела, имају своју функцију и самим тим и значење у тексту, те указује на чињеницу колико је текст изворника сложена структура чији саставни делови и елементи нису тако лако уочљиви, а баш они преводиоца стављају пред тежак задатак да им у систему преводног језика пронађе еквивалентне вредности, а да задржи уметнички и стилски ниво оригинала. И у другим чланцима аутор се бави проблематиком адекватног превођења прозодијских елемената стиха: „Карел Јаромир Ербен као преводилац српскохрватске народне поезије - с гледишта ритмичке структуре његових превода” (1980), „Ритам и ритмичка организација стиха као језички и преводилачки проблем” (1980), „Први стихови српске народне поезије на чешком с гледишта транспозиције основних елемената њихове структуре” (1974), или пак „Семантичка вредност структурних померања у преводу на макро и микро стилистичком плану" (1980) у ком Д. Мирковић подржава принцип функционалне еквивалентности, коју пре свега треба тражити на нивоу структуре израза текста, тј. на нивоу стила, а еквивалентност стила може се изразити на два нивоа: макро и микростилистичком плану тескта. Аутор сматра да је централна и најсложенија област преводиочевих операција област микростилистике, где он у избору адекватних и еквивалентних елемената мора да пође од семантичке вредности функција тих елемената, било да је реч о некој језичко-стилској категорији, или о прозодијским факторима као што су ритам, метар, рима и сл. ${ }^{3}$

Стојанку Поповић пре свега интересовале су дијалектолошке теме. У својој докторској дисертацији, објављеној монографски под називом Говор gвају чешких насеља у Босни (Нова Вес и Мачино Брgо) (1967), и у неколико научних чланака бавила се испитивањима говора прве четири генерације ових чешких насеља. У дисертацији је извршила анализу фонетско-фонолошког и морфолошког система, те утицај српскохрватског система али и украјинског и пољског који је произашао из историјских прилика, на чешки језик, а уклапањем позајмљеница из ових словенских језика у фонетску структуру говора поменутих насеља бавила се у раду "О позајмицама и њиховом продирању у језик чешких насеља у Босни" (1974). У чланку „Резултати испитивања чешких говора у насељима

${ }^{3}$ Био-библиографске податке и приказ одабраних радова Д. Мирковића дала је у свом чланку А. Корда-Петровић (1998). 
Нова Вес (Босна) и Крушчица (Банат)" (1968) испитује са једне стране узајамно прожимање варијаната чешког језика, а са друге утицај српскохрватске језичке структуре на фонетско-фонолошки, морфолошки, творбени и синтаксички систем. Ауторка закључује да је у насељу Нова Вес сукоб варијаната чешког језика довео до свођења на један фонетско-фонолошки систем, а да је у додиру са српскохрватском језичком структуром чешки фонетско-фонолошки систем обогаћен алофонима не увек потпуно асимилираним са сличним гласовима из српскохрватског гласовног система. Говор у селу Крушчица по ауторки представља досељенике из западне и јужне Чешке, западног и јужног дела средње Чешке и можда из прелазног чешко-моравског појаса. Под утицајем српскохрватског језика померила се артикулација извесних гласова, док се у говору млађих генерација сасвим изједначила са сличним српскохрватским гласовима, и у односу на чешке говоре у Босни овај говор, по ауторки, представља даљи развој утицаја српскохрватског језика. ${ }^{4}$

Године 1970. на катедру долази Душан Квапил, још један од доајена српске бохемистике. Д. Квапил је поред наставе на групи за чешки језик свој радни век провео као врсни преводилац, стручњак како за усмене тако и писмене преводе. ${ }^{5}$ Стога не чуди што у својим научним радовима пажњу посвећује транслатолошким проблемима, преводилачкој теорији и пракси. У чланку „Први преводи Андрићеве прозе на чешки језик" (1981) осврће се на преводе настале измећу два рата, којих је било преко 25, захваљујући преводиоцима на чешки језик, као што су Јозеф Пелишек (Josef Pelíšek), затим Јован Кршић, велики познавалац чешке књижевности, потом Бошко Тешановић, и најзад Божена Мерџова (Božena Merdžová) чијем преводу Андрићеве прозе Д. Квапил посвећује највећу пажњу. Сматрајући да је збирка приповедака мајсторски преведена, изузетно схваћена и одлично прокоментарисана, наводи један одломак из приповетке Мосй на Жейи. Изузетно преводилачко умеће аутор приписује стручности и таленту, али и срећној предиспозицији да је била удата за херцеговачког лекара који је студије завршио у Прагу, те је, по мишљењу Д. Квапила, уз његову помоћ могла постићи аутентичност и прецизност у превођењу. И у раду „Проблеми превођења Хашековог 'Швејка' на српскохрватски језик, посебно на његову источну варијанту" (1984) обрађује специфичности чешког језика и избора лексике у овом изузетном делу за чији превод је потребно не само надахнуће и књижевни дар, већ и врхунско познавање језика оригинала. У чланку „Како не

\footnotetext{
${ }^{4}$ Радови С. Поповић обухваћени су такође студијом В. Копривице о дијалектолошким истраживањима чешког језика у српској средини (2012).

${ }^{5}$ О биобиблиографским подацима Д. Квапила писао је Вацлав Штепанек (2011), а његову библиографију саставио је Јаромир Линда (2011).
} 
треба писати ни објављивати стручне материјале са чешком тематиком" (2005) аутор се бави питањима транскрипције чешких имена, проприja, топонима и сл., цитирања извора на чешком и познавањем и преношењем чешких реалија у српску средину. Наводећи бројне неадекватне примере у дневној штампи, па чак и у стручним зборницима, указује на озбиљне грешке и пружа објашњење и могућа решења датих недоумица које представљају правописне, морфолошке и друге специфичности чешког језика које заслужују посебну пажњу код преноса у српски језик или правилног цитирања оригинала, и бројних других. У чланцима „Три Чапекова драмска круга” (1991) и „О преводима и превођењу Чапековог књижевног опуса - досадашњем и будућем" (1994) бавио се адекватношћу преведених дела Карела Чапека на српски језик, будући и сам преводилац његових драма и прозних текстова. ${ }^{6}$

Након десет година (1981) на катедру долази Верица Копривица. У лингвистичка интересовања В. Копривице спадају како питања савременог чешког језика, тако и његове историје, а могу се поделити у више области. Прву област представља проблематика семантике у оквиру морфолошких врста речи, конкретно заменица које обрађује у свом магистарском раду под називом „Значење и употреба неодређених заменица у чешком и српскохрватском језику" (1984). Полазећи од значења неодређености у раду обухвата и речи које нису заменице, али заменичка значења могу изражавати, анализира просте, префиксалне неодређене заменичке речи, неодређене заменичке речи са партикулама, и оне са другим изразима, као и заменичке конструкције, те бројеве и придеве, закључујући да разлике у системима између два језика нису велике, али да су евидентне и причињавају тешкоће приликом превођења, да су нешто веће у изражавању нијанси неодређености, где пресудну улогу имају партикуле, затим да чешки језик садржи више низова за изражавање произвољности, док у српском сличне заменице садрже и допусно значење, те да значење неодређености у чешком изражавају и показне заменице и др. Истом темом, али уз посебан осврт на проблематику усвајања ових јединица чешког језика у српској средини с обзиром на специфичности семантике и функција ауторка се бави и у раду „Неки проблеми превођења и усвајања чешких неодређених заменица” (1991). У чланку „Семантичко поље чешке заменице žádný и њени српскохрватски еквиваленти” (1986) износи пак преглед семантичког поља ове заменице у чешком језику од општег које је негирање постојања предмета и особина, преко негирања добрих особина појма, те у употреби без именице итд., затим њене функције у реченици, као што су атрибутска, субјекатска, објекатска и др., и најзад могућност сврставања у неколико

${ }^{6}$ Радовима Д. Квапила бавила се А. Корда-Петровић (2010). 
врста речи - заменице, бројеве, придеве, упоређујући је са њеним српским еквивалентима до којих анализом бројних примера долази.

Значајна област интересовања В. Копривице тиче се дериватологије. Системом деадјективних именица у чешком и српском језику бавила се у својој докторској дисертацији, објављеној и монографски Творба именица оg ирияева у чешком и срйском језику (2006) у којој врши конфронтативну творбену анализу на нивоу ономасиолошких и творбених категорија, спуштајући се затим на план творбених типова. На основу богатог материјала који детаљно упоређује, стављајући акценат на најситније формалне и семантичке разлике, ауторка закључује да у оквиру суфиксације постоји подједнак број типова у оба језика, а у осталим творбеним поступцима, као што су универбизација, супстантивизација, конверзија и десуфиксација, чешки језик показује знатно већу продуктивност. Најзначајније разлике запажа на нивоу творбених типова, у инвентару и продуктивности, а постоје и разлике у заступљености и обиму појединих лексичко-семантичких група. ${ }^{7}$ Више студија произашло је из овог обимног истраживања, те ауторка нпр. у чланку „Супстантивизација придева мушког рода у чешком и српском језику" (2004) наводи и анализира типове придева у оба језика, закључујући да чешки језик садржи много већи број именица са више суфиксалних образаца мотивних придева, те да је продуктивност десетоструко већа него у српском језику. Деадјективне именице твробене категорије носилаца особина разматра у раду „Лексичкосемантичке групе као полазиште за конфронтативну анализу деривационих система два словенска језика" (2012) и долази до закључка да се та категорија у чешком и српском језику не разликује системски, као да ни на нивоу творбених типова нема битнијих разлика. Међутим, што се пореде нижи нивои творбеног система ова два језика, као што су лексичке групације унутар творбених подтипова и лексичкосемантичких група, наилази се на све веће разилажење. Тему супстантивизације са творбено-семантичког и морфолошког гледишта обрађује у чланку „Именице са придевском деклинацијом у чешком и српском језику" (2003), док своје проучавање проширује и на словачки језик у раду „Творба деадјективних супстантива у чешком, словачком и српском језику - творба суфиксацијом” (2003). У студији „Именице са суфиксом -ица у атрибутској функцији и њихови чешки еквиваленти" (2009) ауторка полази од српског језика анализирајући тврбену структуру и функцију именица са датим суфиксом и проналази преводне еквиваленте у чешком језику. Закључује да у чешком језику само изузетно

${ }^{7}$ Детаљније о овом истраживању писале су В. Копривица и К. Митрићевић-Штепанек $(2010,2011)$. 
постоји тврбени еквивалент, те да се у тој функцији користи синтагма придев+именица.

Развојем језика ауторка се бавила у неколико студија. У чланку "Савремени чешки и српски књижевни језик - развој и перспективе” (2005) ставља акценат на различитости друштвено-политичких и културних услова настанка и развоја српског и чешког књижевног језика, те на основне тенденције њиховог будућег развоја. Док је у развоју чешког књижевног језика постојао континуитет, у српском је развој био испрекидан, чешки језик има извориште у једном центру, док је у српском постојало неколико развојних центара, нови књижевни чешки језик је усмерен на писану форму, док је Вуков језик окренут говорном типу. Такође, структурна разлика између књижевног и свакодневног говорног језика је у чешком знатна, а у српском занемарљива, чешки показује мању тенденцију ка толерисању страних елемената, док је српски по том питању толерантнији. Ауторка закључује да чешки књижевни језик својим принципима непрестане бриге за очување језика и способношћу да ослушкује све промене у језичкој пракси и узусу може да послужи као модел у борби за очување малих језика. Посебну пажњу савременим тенденцијама у ова два језика, са освртом на функционалну диференцијацију, посвећује у раду „Неке нове тенденције у разговорном српском језику у поређењу са чешким" (2006) истичући да по питању структурне разлике имеђу књижевног језика и свакодневног говора, која је у чешком језику за разлику од српског знатна, у новије време постоји тенденција да се ова два идиома и у српском све изразитије диференцирају. Утицај чешког језика на српски у области творбе речи и графијског система, као и преузимање чешких елемената у српском језику које се одвијало на нивоу лексема разматра у студији „О бохемизмима у српском језику” (2008), наводећи мноштво примера преузимања творбених модела, лексема из периода хуманизма и периода хуситских ратова, народног препорода, док је савремено преузимање лексема епизодијског карактера и ради се о речима које имају карактер интернационализама.

Допринос чешко-српској лексикографији В. Копривица дала је као аутор речника Чешко-срйски и срйско чешки реиник (2008) који садржи нешто више од 20000 речи и широко је заснован како би представио основне појмове из већине области са којима корисник, а превасходно српски, може да се сретне у иностраној језичкој средини. Садржи и објашњења специфичности чешког језика, абецеду, изговор, преглед граматике, као и најчешће чешке и српске изразе из свакодневног живота. Одреднице су пажљиво одабране узимајући у обзир савремени језик и његов развој у бројним областима и стиловима.

Природно, ни област усвајања језика није остала по страни научних интересовања В. Копривице. У радовима као нпр. „Главни проблеми 
усвајања граматике у савременој настави инословенског језика" (2010), „Настава фонетике и фонологије чешког језика у српској средини” (2016) истиче важност примене адекватног метода код обучавања чешком језику, где је неопходна равнотежа у примени комуникативног метода и традиционалнијих метода, као што је нпр. граматичко-преводни метод, те да је комбиновање ова два метода неопходно у настави једног словенског језика у инословенској средини, а исто тако да конфронтативни приступ, са ослањањем дакле на матерњи језик, има велике предности. Чешки и српски као сродни језици не показују битније разлике у структурном типу и језичким универзалијама, те се разлике морају тражити претежно у функционисању појединих граматичких категорија, а специфичности ауторка уочава на свим језичким нивоима (акценат, квантитет вокала, графички принцип, категорија претериталних времена, итеративности, функције показних и неодређених заменица, синтаксичка функција инфинитива, разлике на нивоу ситнијих делова творбених категорија и сл.). ${ }^{8}$

Питањима ортографије В. Копривица бави се у чланку „О транскрипцији чешких имена" (1988) где нуди решења за њихову што прецизнију адаптацију с уважавањем историјског развоја оба језика и могућностима савременог стања, посвећујући посебну пажњу специфичним графемама чешког језика које српски језик нема (е̌, d', t’' ř $)$, те области морфологије у којој је због чешких гласовних промена дошло до великих удаљавања деклинација, тако да немале проблеме представља препознавање рода и броја чешких топонима и антропонима.

У међувремену се Група за чешки језик проширивала и њен састав се мењао, да би постепено током прве декаде двехиљадитих њени чланови у настави чешког језика постали Катарина Митрићевић-Штепанек (1999), Јаромир Линда (2002) и Снежана Поповић (2012).

У радовима К. Митрићевић-Штепанек преовладава интересовање за област дериватологије и лексикологије. Заступљен је творбено-семантички приступ језичким јединицама, као нпр. деминутивима, којима се бави у свом магистарском раду „Значење и употреба деминутива у чешком језику и њихови еквиваленти у српском језику" (2005) у ком анализира систем именичких деминутива у чешком језику и утврђује њихове формалне и семантичке еквиваленте у српском језику. ${ }^{9}$ Ауторка

${ }^{8}$ Као помоћно средство за усвајање чешког језика В. Копривица написала је и

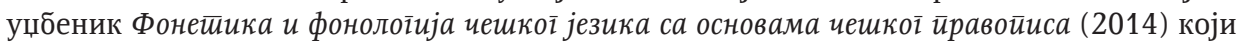
представља теоријски курс из фонетике и фонологије чешког језика, уз изводе из чешких ортографских правила који се односе на бележење и изговор гласова и фонема у чешком. 2011)

${ }^{9}$ О овом раду писале су такође В. Копривица и К. Митрићевић-Штепанек (2010, 
врши њихову поделу на три главна значења - право деминутивно значење изражава појам који је са гледишта нормалних пропорција мали, затим експресивно значење којим деминутиви указују на појам који садржи позитивну или негативну субјективну оцену, и треће, формално значење код којег се деминутиви лексикализују или специјализују на основу метафоричног и метонимијског преноса основног значења, и тако именују сасвим нови, засебни појам. Из ових значења дакако се развијају даља подзначења, а њихова широка скала омогућава им употребу у разним конструкцијама и контекстима. Анализа деминутивих еквивалената у српском језику наводи ауторку на закључак да је лексички фонд деминутива у српском језику далеко скромнији, као и да је њихова фреквенција нижа, а употреба не у тој мери широка у односу на чешки језик. Истом темом бавила се и у више радова произашлих из овог проучавања, као нпр. у чланку „Позитивна субјективна оцена у оквиру експресивног деминутивног значења у чешком и српском језику" (2007) пажњу усмерава на деминутиве који имају експресивно значење и изражавају позитивну субјективну оцену у чешком језику, прецизира дато значење и утврђује формалне еквиваленте и друге начине транспозиције у српском језику, затим у раду „Деминутиви у функцији набрајања и конфронтације у чешком и српском језику" (2007) ауторка анализира употребе деминутива у функцији изражавања неких односа између великог (нормалног) и малог појма, у чланку „Деминутиви са пејоративним значењем у чешком и српском језику" (2010) скреће пажњу на деминутиве у функцији пејоратива, код којих се негативни став постиже омаловажавањем појма и иронијом, док у раду „Деминутиви као средства интензификације у чешком језику и њихови еквиваленти у српском језику" (2013) ауторка анализира деминутиве у функцији интензификације особине појма који је изражен деминутивима, а постиже се на два начина: употребом деминутива другог степена и модификацијом значења мали. У студији „Конфронтативно проучавање чешког и српског језика на примеру деминутива изведених секундарним суфиксима" (2012) ауторка у складу са традиционалним конфронтативним проучавањем чешког језика у српској средини анализира деминутиве у чешком језику изведене секундарним суфиксима, истиче њихов специфичан положај у оба језика, наводи творбена средства, анализира односе са првостепеним деминутивима, прецизира њихово значење, наводи функције и нуди могућа решења проблема који настају код превођења ових изведеница на српски језик. Глаголским префиксима и њиховим дериватима К. Митрићевић-Штепанек бави се у докторској тези под називом „Глаголски префикси у функцији изражавања количине радње у чешком и српском језику" (2015) вршећи истраживање које се заснива на анализи глаголских префикса који изражавају семантичку црту квантитета, пре- 
цизније, велике и мале количине радње, у чешком језику и њихових еквивалената у српском језику. Ауторка издваја глаголске префиксе који у чешком језику изражавају семантику квантитета, наводи и анализира њихова појединачна значења и утврђује формалне и семантичке еквиваленте у српском језику, прецизира преводну семантизацију, анализира подударање лексикографских и контекстуалних еквивалената и нуди решења у виду различитих начина транспозиције узимајући у обзир комуникативну функцију целог исказа. На основу анализиране грађе закључује да семантичку црту квантитета изражавају глаголски префикси у оба језика, али по питању велике количине радње у српском језику упола мање средстава учествује у изражавању те семантике, док је код изражавања мале количине радње тај однос приближнији, али поново у корист чешког језика. Префиксалним дериватима ауторка се бавила и у чланку „Префиксација као процес интеграције глаголских позајмљеница у чешком и српском језику" (2012) у ком разматра процес адаптације и интеграције глагола страног порекла који се одвија како у чешком, тако и у српском језику, анализира у којој мери је процес префиксације у овим језицима развијен, која творбена средства су најпродуктивнија и наводи најчешће типове међујезичке еквиваленције. У раду „Семантика 'уништења/оштећења објекта' глагола са префиксом $y$ - у чешком језику и њихови еквиваленти у српском језику" (2015) анализира дате префиксалне глаголске изведенице у чешком језику које изражавају семантику уништити/оштетити објекат сталном или честом радњом и скреће пажњу на чињеницу да префикс у- у српском језику не изражава дато значење, те да се у вези са тиме испољава само семантичка еквиваленција, коју може чинити изведеница грађена другачијим префиксом са истим или приближним значењем и други начини транспозиције, као што су опис значења и устаљени изрази. Истом глаголском префиксу посвећен је чланак „Глаголски префикс $y$ - са значењем 'извршити кратку вербалну или мимичку радњу' у чешком језику и његови еквиваленти у српском" (2016) у ком ауторка утврђује на основу грађе да само значење није нарочито продуктивно у чешком језику, а да су обухваћени такви глаголи који означавају неку краћу мимичку радњу лица, усана, или пак вербалну радњу, да у српском језику постоје само два семантичка еквивалента у виду префиксалних глагола.

С обзиром на то да смо чланак посветили превасходно лингвистичкој тематици, од богате књижевноисторијске и текстолошке продукције Јаромира Линде овде помињемо само студију „Významná památka předspisovné slovenštiny z roku 1750 - Universae Phraseologiae Latinae corpus" (Значајан споменик преткњижевног словачког језика из 1750. године - Universae phraseologiae Latinae corpus) у којој се аутор бави вероватно најстаријом књигом у фондовима библиотеке Катедре за 


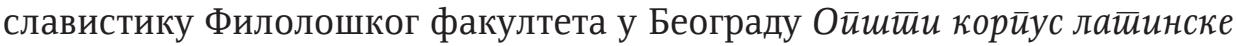
фразеолоїије Франца Вагнера који је био објављен у Трнави 1750. године. Уз пример две лексичке одреднице даје кратак опис речника и карактеристика како преткњижевног западнословачког језика тако и општих језичких и културних веза са другим чешким и словачким речницима и закључује да основну базу израза и фразема у поменутом речнику чини словакизовани чешки језик.

Облашћу лексикологије, а превасходно фразеологијом бави се Снежана Поповић. У својој докторској тези „Česká a srbská frazeologie. Srovnání, aspekty a struktura česko-srbského frazeologického slovníku" (Чешка и српска фразеологија. Поређење, аспекти и структура чешко-српског фразеолошког речника) (2016) анализира теорију чешке и српске фразеологије, класификацију фразема и фразеолошку праксу, укључујући теоријска полазишта за израду преводног фразеолошког речника, као и предлог самог речника. Анализу врши у области дефинисања фразема, њихове формалне поделе, еквивалената на свим нивоима комбиновања и концепције одреднице у фразеолошким речницима, како описним, тако и преводним. Ауторка закључује да постоје области у оквиру фразеологије којима није посвећена једнака пажња, као што је нпр. питање квазифразема, и да терминологија у области српске, српскохрватске и чешке фразеологије не спада у сасвим разјашњену област, затим да су могућности комбиновања фразема у оба језика сличне што потврђује висок број формалних и семантичких еквивалената на лексичком, колокацијском и реченичном нивоу. Посебну вредност овом истраживању даје прилог у виду чешко-српског фразеолошког речника соматизама који представља корисно средство за студенте и наставнике бохемистике, као и за преводиоце. И у појединачним студијама С. Поповић се бавила истом проблематиком, као рецимо у раду „Frazém v srbské a české lingvistice - pojetí a terminologie" (Фразем у српској и чешкој лингвистици - схватање и терминологија) (2012) у ком прадставља стање у српској фразеолошкој терминологији и даје дефиниције фразема које су уско повезане са називима за ову основну јединицу фразеологије, док истовремено упоређује ситуацију у чешкој лингвистици у вези са дефинисањем фразема, закључујући да у српској фразеолошкој лингвистици недостаје нормативни приступ у оквиру терминологије и код конкретног дефинисања фразема, али да је развој фразеолошке терминологије евидентан. У студији „Formální a sémantické charakteristiky frazémů v srbském a českém jazyce" (Формалне и семантичке карактеристике фразема у српском и чешком језику) (2015) бави се двама карактеристикама фразема које фразеолози најчешће истичу, а то су устаљеност израза, тј. његова формална страна, и семантичка промена макар једног члана скупа. Анализирајући став о основним карактеристика фразема српс- 
ких, хрватских, чешких и словачких лингвиста доноси закључке о формалним особинама ове основне јединице фразеологије као и о њеним семантичким односима. Проблематици лексикалних фразема ауторка се посвећује у чланку „Комбинаторика у фразеологији на примјерима лексикалних фразема у српском и чешком језику" (2015) где на примерима комбинација у нерегуларном језику, тј. у фразеологији, приказује богатство комбиновања наводећи примере лексикалних фразема у чешком и српском језику, које упоређује у семантичком, формалном и идиоматском смислу и закључује да број еквивалената није занемарљив како у погледу општег лексикона оба језика тако и због чињенице да је осим идиоматске еквивалентности висока и формална подударност, одн. творбена еквивалентност. У раду „Квазифраземи у српском и чешком језику" (2013) настоји да идентификује скупове речи у српском језику који се налазе на граници фразеологије и познати су под називом квазифраземи, дајући њихову поделу, као нпр. изрази са конкретним денотатом, терминолошки изрази, изрази са синсемантичким компонентама, изрази са ограниченом колакабилношћу компонената и др., и закључује да они представљају значајни део лексикона, да нису само колокације, већ изрази који су прекорачили границе регуларног језика и нашли широку примену. У студији „Tautologické výrazy ve frazeologii” (Таутолошки изрази у фразеологији) (2015) истражује дате исказе које сматра фраземима на чешким, српским и руским примерима, уз њихову поделу на биноминалне и реченичне, истичући да њихову устаљеност, тј. припадност области фразеологије, потврђује тест комутације којим је утврђена немогућност парадигматске замене, али и да је упркос непостојању потпуне десемантизације присутна идиоматизација, која не би смела бити занемарена. У раду „Фраземи са значешем 'никад' у чешком и српском језику" (2016) бави се колокацијама и реченицама са овим темпоралним значењем дајући специфичности њихове структуре и значења, класификујући их на основу њихове структуре и облика и изводи закључак да фразеологија показује више сличности него разлика, а на примеру обрађених фразема ауторка показује да би било корисно и у српском језику применити смер од семантике ка устаљености као још један вид лакшег регистровања и проналажења нових израза. У неколико радова С. Поповић бави се питањем фразеографије - структуром и избором речничких одреница, анализом на примерима два једнојезичка и два преводна фразеолошка речника, критеријумима за одабир саставних делова одреднице, могућностима и границама чешко-српског фразеолошког речника које се тичу досадашњих извора, проблемима коришћења електронских извора у сврху компаративног лексикографског истраживања с обзиром на његове недостатке у српској средини и сл.: „Struktura a výběr hesel budoucího česko-srbského 
frazeologického slovníku" (Структура и избор одредница будућег чешко-српског фразеолошког речника) (2011), „Možnosti a hranice českosrbského frazeologického slovníku" (Могућности и границе чешко-српског фразеолошког речника) (2010) и „Česko-srbský frazeologický slovník a srbské elektronické zdroje" (Чешко-српски фразеолошки речник и српски електронски извори) (2010).

Питањима лексикографије С. Поповић бавила се и ван области фразеологије, као нпр. у радовима „Lexikální srbismy/srbocharvátismy v SSJČ a elektronické slovníky češtiny" (Лексикални србизми/србокроатизми у SSJČ и електронски речници чешког језика) (2011) и „Позајмљенице из јужнословенских језика у Речнику књижевног чешког језика" (2010) у којима утврђује позајмљенице из српског/српскохрватског, одн. из јужнословенских језика, и покушава да одреди њихово стварно порекло и начин на који су доспеле у чешки језик, а њихову фреквентност у савременом чешком језику проверава помоћу Чешког националног корпуса, закључујући да је већина тих речи данас изашла из употребе, те да се оне са сигурношћу могу карактерисати као архаичне.

У овом прегледу није нам био циљ да наведемо исцрпну библиографију, већ да на основу одабраних радова укажемо на развој интересовања за лингвистичку бохемистичку проблематику у српској средини и на допринос српске бохемистике проучавању чешког, али и српског језика, с обзиром на то да је великој већини радова заједнички конфронтативни приступ јединицама ова два језика.

\section{ЦИТИРАНИ РАДОВИ}

Квапил, Душан, „Први преводи Андрићеве прозе на чешки језик”, Научни састанак слависта у Вукове дане 4, 1980, 2, 95-99.

-, „О преводима и превођењу Чапековог књижевног опуса - досадашњем и будућем", Савременик плус, Књижевни часопис 15/17, 1994, 58-61.

Копривица, Верица, „О транскрипцији чешких имена”, Славистички зборник 3, 1988, 61-65.

-, „Творба деадјективних супстантива у чешком, словачком и српском језику. Творба суфиксацијом", Život slova v dejinách a jazykových vztahoch (Na sedemdesiatiny profesora Jána Dorulu), 2003, 187-199.

-, „Именице са придевском деклинацијом у чешком и српском језику”, Српски језик, 8, 2003, 1-2, 267-278.

-, „Супстантивизација придева мушког рода у чешком и српском језику”, Славистика 7, 2004, 369-374

-, „Савремени чешки и српски књижевни језик - развој и перспективе”, Славистика 9, 2005, 296-302.

-, „Неке нове тенденције у разговорном српском језику у поређењу са чешким", Studia Balcanica Bohemo-Slovaca VI, 2006, 2, 855-859. 
-, Творба имении, og йрияева у чешком и срйском језику, Београд, Филолошки факултет 2006, 195 стр.

-, „О бохемизмима у српском језику", Славистика 12, 2008, 371-376.

-, „Именице са суфиксом -ица у атрибутској функцији и њихови чешки еквиваленти", Славистика 13, 2009, 327-333.

-, „Главни проблеми усвајања граматике у савременој настави инословенског језика", Славистика 14, 2010, 384-388.

-, „Лексичкосемантичке групе као полазиште за конфронтативну анализу деривационих система два словенска језика", Творба речи и њени ресурси у словенским језицима, 2012, 601-608.

-, Фонейика и фонолоїија чешкої језика са основама чешкоі̄ ӣравойиса, Београд, Славистичко друштво Сробије, 2014, 127 стр.

-, „Настава фонетике и фонологије чешког језика у српској средини”, Савремено изучавање српског језика и књижевности и словенских језика као матерњих, инословенских и страних 2, 2016, 35-43.

Мирковић, Драгутин, „Семантичко-синтаксичке функције прозодијских елемената структуре стиха и њихова еквивалентност у уметничком преводу", Анали Филолошког факултета 11, 1974, 251-285.

-, „Први стихови српске народне поезије на чешком с гледишта транспозиције основних елемената њихове структуре", Научни састанак слависта у Вукове дане, 4, 1974, 1, 549-564.

-, „Семантичка вредност структурних померања у преводу на макро и микро стилистичком плану", Научни састанак слависта у Вукове дане, 10, 1980, 2, 211-220.

Митрићевић-Штепанек, Катарина, „Префиксација као процес интеграције глаголских позајмљеница у чешком и српском језику", Opera Slavica 22, 2012, 2, 11-22.

-, „Конфронтативно проучавање чешког и српског језика на примеру деминутива изведених секундарним суфиксима", Славистика 16, 2012, 531542.

-, „Деминутиви као средства интензификације у чешком језику и њихови еквиваленти у српском језику", Славистика 17, 2013, 336-346.

-, „Семантика 'уништења/оштећења објекта' глагола са префиксом у- у чешком језику и њихови еквиваленти у српском језику", Славистика 19, 2015, 162-170.

-, „Глаголски префикси у функцији изражавања количине радње у чешком и српском језику", Докторска дисертација, Филолошки факултет, Београд 2015.

-, „Глаголски префикс у- са значењем 'извршити кратку вербалну или мимичку радњу' у чешком језику и његови еквиваленти у српском", Славистика 20, 2016, 687-693

Поповић, Снежана, „Комбинаторика у фразеологији на примјерима лексикалних фразема у српском и чешком језику", Зборник Матице српске за славистику 88, 2015, 233-243.

-, „Фраземи са значешем 'никад' у чешком и српском језику”, Славистика 20, 2016, 694-699. 
Поповић, Стојанка, „Резултати испитивања чешких говора у насељима Нова Вес (Босна) и Крушчица (Банат)", Анали Филолошког факултета 8, 1968, 144-159.

-, „О позајмицама и њиховом продирању у језик чешких насеља у Босни”, Анали Филолошког факултета 11, 1974, 387-403.

Koprivica, Verica, „Značenje i upotreba neodređenih zamenica u češkom i sroskohrvatskom jeziku", Магистарски рад, Филолошки факултет, Београд 1984.

-, „Semantičko polje češke zamenice žádný i njeni srpskohrvatski ekvivalenti”, Studia philologica 1-2, 1986, 61-66.

-, „Neki problemi prevođenja i usvajanja čeških neodređenih zamenica”, Живи језиuи - зборник раgова 2, 1991, 207-211.

-, Češko-srpski i srpsko-češki rečnik, Београд 2008, 540 стр.

Kvapil, Dušan, „Problemi prevođenja Hašekovog 'Švejka' na srpskohrvatski jezik, posebno na njegovu istočnu varijantu", Acta Universitatis Carolinae, Philologica, Slavica Pragensia 24, 1984, 175-179.

-, „Tri Čapekova dramska kruga”, Сцена, Часопис за позоришну уметност 27, 1991, 3, 19-26.

-, „Kako ne treba pisati ni objavljivati stručne materijale sa češkom tematikom”, Славистика 9, 2005, 342-346.

Linda, Jaromír, „Významná památka předspisovné slovenštiny z roku 1750 - Universae Phraseologiae Latinae corpus", Slovakistický zborník, Slovakistická vojvodinska spoločnost' Novi Sad, 4, 2009, 54-62.

Mirković, Dragutin, Govori Čeha u Slavoniji (Daruvar i okolina), Филолошки факултет, Београд ,1968, 390 стр.

-, „Karel Jaromir Erben kao prevodilac srpskohrvatske narodne poezije - s gledišta ritmičke strukture njegovih prevoda", Књижевност и језик, 27, 1980, 1, 32-42.

-, „Ritam i ritmička organizacija stiha kao jezički i prevodilački problem”, Књижевност и језик, 27, 1980, 3, 283-295.

Mitrićević-Štepanek, Katarina, „Značenje i upotreba deminutiva u češkom jeziku i njihovi ekvivalenti u srpskom jeziku", Магистарски рад, Филолошки факултет, Београд 2005.

-, „Pozitivna subjektivna ocena u okviru ekspresivnog deminutivnog značenja u češkom i srpskom jeziku", Славистика 11, 2007, 303-319.

-, „Deminutivi u funkciji nabrajanja i konfrontacije u češkom i srpskom jeziku”, Opera Slavica 17, 2007, 4, 18-28.

-, „Deminutivi sa pejorativnim značenjem u češkom i srpskom jeziku”, Славистика 14, 2010, 247-259.

Popović, Snežana, „Pozajmljenice iz južnoslovenskih jezika u 'Rečniku književnog češkog jezika'", Славистика 14, 2010, 238-246.

-, „Možnosti a hranice česko-srbského frazeologického slovníku”, Polyslav 13, Beiträge der Europäischen Slavistischen Linguistik, 2010, 194-198.

—, „Lexikální srbismy/srbocharvátismy v SSJČ a elektronické slovníky češtiny”, Od Moravy k Moravě 2, 2011, 407-425. 
-, „Struktura a výběr hesel budoucího česko-srbského frazeologického slovníku”, Славистика 15, 2011, 237-245.

-, „Česko-srbský frazeologický slovník a srbské elektronické zdroje”, Varia 20, Zborník plných príspevkov z XX. kolokvia mladých jazykovedcov, 2012, 460-465

-, „Frazém v srbské a české lingvistice - pojetí a terminologie”, Славистика 16, 2012, 543-548.

-, „Kvazifrazemi u srpskom i češkom jeziku”, Славистика 17, 2013, 347-351.

-, „Formální a sémantické charakteristiky frazémů v srbském a českém jazyce”, Славистика 19, 2015, 249-252.

-, „Tautologické výrazy ve frazeologii”, Aktuální problémy současné slavistiky (jazyk - literatura - kultura - politika), 2015, 285-290.

-, „Česká a srbská frazeologie. Srovnání, aspekty a struktura česko-srbského frazeologického slovníku", Disertační práce, Filozofická fakulta, Praha 2016.

Popović, Stojanka, Govor dvaju čeških naselja u Bosni (Nova Ves i Mačino Brdo), Филолошки факултет, Београд 1967, 165 стр.

\section{ЛИТЕРАТУРА}

Квапил, Душан, Копривица, Верица, Корда-Петровић, Александра, „Катедра бохемистике на Одсеку за славистику Филолошког факултета у Београду - историјат и перспективе", Славистика 4, 2000, 151-160.

Копривица, Верица, „Дијалектолошка истраживања српских бохемиста”, Славистика 16, 2012, 502-507.

Копривица, Верица, Митрићевић-Штепанек, Катарина, „Контрастивна изучавања српског и чешког језика", Контрастивна проучавања српског језика: правци и резултати 1, 2010, 155-177.

- -, „Настава чешког језика на Филолошком факултету у Београду”, Od Moravy k Moravě II. Z historie česko-srbských vztahů v 19. a 20. století/ Од Мораве до Мораве II. Из историје чешко-српских односа у 19. и 20. веку, 2011, 397-406.

Корда-Петровић Александра, „Душан Квапил (11. VIII 1934 - 21. VII 2009)”, Славистика 14, 2010, 412-414.

Линда, Јаромир, „Библиографија Душана Квапила (*11. 08. 1934. Осијек - † 21. 07. 2009. Београд)", Od Moravy k Moravě II. Z historie česko-srbských vztahů v 19. a 20. století/ Од Мораве до Мораве II. Из историје чешко-српских односа у 19. и 20. веку, 2011, 9-16.

Jančák Pavel, „Kniha o nářečích jugoslávských Čechů, Naše řeč 53, 1970, 2, 94-101.

Korda-Petrović, Aleksandra, „Dragutin Mirković (30. 8. 1921 - 15. 3. 1998)”, Slavia 67, 1998, 3, 443-444.

Štěpánek, Václav, „Dušan (Duško) Kvapil - srbský bohemista, překladatel a přední propagátor česko-srbské vzájemnosti", Od Moravy k Moravě II. Z historie česko-srbských vztahů v 19. а 20. století/ Од Мораве до Мораве II. Из историје чешко-српских односа у 19. и 20. веку, 2011, 5-8. 
Katarina Mitrićević-Štepanek

\title{
LINGUISTIC RESEARCH OF THE CZECH LANGUAGE AT THE DEPARTMENT OF SLAVONIC STUDIES OF THE FACULTY OF PHILOLOGY AT THE UNIVERSITY OF BELGRADE
}

\begin{abstract}
Summary
Presented paper was dedicated to linguistic research of professors and fellows of the Czech Language Seminar at the Department of Slavonic Studies of the Faculty of Philology at the University of Belgrade (Serbia). It gives a list of studies, published in both Serbian and Foreign magazines, as well as monographs and doctoral and M.A. works, which represent a contribution to research of the Czech language in Serbian society, giving deeper view of the development of scientific interests within the framework of linguistic Bohemistics.

Key words: slavonic studies, serbian bohemistics, czech language, linguistic research
\end{abstract}

